\title{
Effect of Silica on Physical and Biochemical Characters of Guava
}

\author{
Kishore Kumar Das ${ }^{1 *}$, G.S.K. Swamy ${ }^{2}$, Shivaningapp Kumbar ${ }^{3}$, \\ P.M. Gangadharappa ${ }^{4}$ and R.C. Jagadeesha ${ }^{3}$ \\ ${ }^{1}$ Swami Keshwanand Rajasthan Agriculture University, Bikaner- 334006, Rajasthan, India \\ ${ }^{2}$ College of Horticulture, Mysore- 571130, Karnataka, India \\ ${ }^{3} \mathrm{KRC}$ College of Horticulture, Arabhavi-591218, Karnataka, India \\ ${ }^{4}$ College of Horticulture, Koppala-583234, Karnataka, India \\ *Corresponding author
}

\section{A B S T R A C T}

Keywords

Guava,

Diatomaceous

Earth, Silicon,

Physical and

Biochemical

Characters.

Article Info

Accepted:

15 March 2017

Available Online:

10 April 2017
An experiment was carried out in Kittur Rani Channamma College of Horticulture, Arabhavi, Karnataka to study the effect of silica (Diatomaceous earth) on physical and Biochemical characters of Guava. Diatomaceous earth is a source of silicon and it was applied after bahar treatment as whole basal application along with recommended dose of fertilizer. Maximum fruit weight $(150.99 \mathrm{~g})$, volume $(165.95 \mathrm{ml})$, length $(65.30 \mathrm{~mm})$, girth $(70.82 \mathrm{~mm})$, peel weight $(1.33 \mathrm{~g})$, TSS $\left(12.05^{\circ} \mathrm{B}\right)$, sugars to acid ratio (71.05), minimum acidity $(0.18 \%)$, reducing sugar $(5.04 \%)$, non reducing sugar $(6.11 \%)$, total sugar $(11.15 \%)$ and ascorbic acid $(172.95 \mathrm{mg} /$ $100 \mathrm{gm})$ was recorded in $\mathrm{T}_{9}(\mathrm{RDF}+3 \mathrm{~kg}$ of $\mathrm{DE} / \mathrm{plant})$ while the minimum values were recorded in treatment $\mathrm{T}_{1}$ (Absolute control).

\section{Introduction}

Guava (Psidium guajava L.) member of family Myrtaceae, popularly known as the "Apple of the Tropics", is one of the most common fruits grown in India. Presently, it is widely grown all over the tropics and subtropics. Guava has gained considerable prominence on account of its high nutritive and medicinal values, availability at moderate prices, pleasant aroma and good flavour. It is a rich source of vitamin $\mathrm{C}$, pectin, moderately good source of iron, calcium and a fair source of phosphorus. Guava is one of the richest sources of dietary fibre. The presence of vitamin $\mathrm{C}$ and other phyto nutrients, such as carotenoids, isoflavonoids and polyphenols, in guava has led to it being an effective antioxidant. Leaves of guava have medicinal properties. The juice of the leaves is said to provide relief from cold, cough and diarrhoea. Apart from being relished as fresh fruit when fully mature or ripe, it is extensively used for making jelly and to a limited extent for juice, fruit jam and canning in sugar syrup or made into fruit butter. It freezes exceptionally well and the products are practically indistinguishable from fresh fruits. The crop is quite hardy, prolific bearer and highly remunerative even without much care. Guava can be successfully grown under tropical and 
sub-tropical climate. The crop production of guava can be increased by balanced nutrition on profitable basis even though it is growing in the tropical condition. The growth, yield and quality of guava can be increased by application of manures and fertilizers as it respond to application of fertilizers. Silicon is the most abundant element in the earth's crust region next to oxygen and comprises 28 per cent of its weight, out of which 3-17 per cent is present in soil solution (Epstein 1999). It is most commonly found in soils in the form of solution as silicic acid $\left(\mathrm{H}_{4} \mathrm{SiO}_{4}\right)$ and is taken up directly as silicic acid (Ma et al., 2001). Being a dominant component of soil minerals it has many important functions in environment, although silicon is not considered as an essential plant nutrient because of its ubiquitous presence in the biosphere and most plants can be grown from seed to seed without its presence. The role of silicon in plant biology is to reduce multiple stresses including biotic and abiotic stresses. It is also known to increase drought tolerance in plants by maintaining plant water balance, photosynthetic activity, erectness of leaves and structure of xylem vessels under high transpiration rates (Melo et al., 2003). Silicon application improved water economy and dry matter yield (Gong et al., 2003). It enhanced the leaf water potential under water stress conditions, reduced the incidence of micronutrient and metal toxicity (Matoh et al., 1991).

The presence of Silicon also been reported to affect the absorption and translocation of several macro and micro-nutrients. $\mathrm{Si}$ is accumulated in plants to total concentrations in dry matter similar to those of essential macro-nutrients such as Potassium, Calcium, Magnesium, Sulphur and Phosphorous (Epstein, 1999). Silicon has positive growth effect including increased dry mass and yield, enhanced pollination and most commonly increased disease resistance (Gillman et al.,
2003). Realizing the beneficial effects of silicon in sustainable crop production and the response of several crops to silicon nutrition for sustained crop yield diatomaceous earth (DE) is used as silicon source in the present experiment. With this brief information and based on the possible benefits of silicon, the present study was carried out to know the effect of Diatomaceous Earth (as source of silicon) on physical and Biochemical characters of Guava.

\section{Materials and Methods}

The present investigation was carried out at Kittur Rani Channamma College of Horticulture, Arabhavi (University of Horticulture Sciences, Bagalkot), Gokak talus of Belgaum district, Karnataka. The Sardar (L-49) variety of guava is used for experiment. The source of silicon used is Diatomaceous earth (DE), applied as basal dose to the respective treatment in this experiment. The dosage of DE used in this experiment was 1,2 and $3 \mathrm{~kg} /$ plant. The inorganic nutrient i.e. nitrogen was applied in the form of urea $(46 \% \mathrm{~N})$, phosphorous in the form of single super phosphate (16\%) and potassium in the form of muriate of potash $(60 \% \mathrm{~K})$. These nutrients were applied to the respective treatment according to the package of practice of UHS, Bagalkot.

The design adopted for the experiment was Randomized Block Design (RBD) and the treatment details are $\mathrm{T}_{1}$ - Absolute control, $\mathrm{T}_{2}$ - Recommended dose of fertilizer (200:80:150 g NPK/plant), $\mathrm{T}_{3}$ - Half of Recommended dose of fertilizer, $\mathrm{T}_{4}$ - Half of $\mathrm{RDF}+1$ $\mathrm{kg} /$ plant of DE, $\mathrm{T}_{5}-$ Half of RDF $+2 \mathrm{~kg} /$ plant of DE, $\mathrm{T}_{6}-$ Half of RDF $+3 \mathrm{~kg} / \mathrm{plant}$ of DE, $\mathrm{T}_{7}$ - RDF + 1kg/plant of DE, $T_{8}-\mathrm{RDF}+2$ $\mathrm{kg} /$ plant of DE, $\mathrm{T}_{9}-\mathrm{RDF}+3 \mathrm{~kg} /$ plant of DE. The fruits were harvested at matured stage and observation on fruit weight, fruit volume, fruit length, girth and biochemical parameters 
like TSS, titratable acidity, sugars and ascorbic acid were recorded.

\section{Results and Discussion}

The effect of diatomaceous earth on fruit characters of guava is presented table 1, The Maximum values for fruit characters like weight $(150.9 \mathrm{~g})$, volume $(165.95 \mathrm{ml})$, girth $(70.82 \mathrm{~mm})$, length $(65.30 \mathrm{~mm})$ and peel weight $(1.33 \mathrm{~g})$ was recorded in $\mathrm{T}_{9}(\mathrm{RDF}+3$ $\mathrm{kg} \mathrm{DE} /$ plant)and the minimum fruit weight $(104.30 \mathrm{~g})$, fruit volume $(124.00 \mathrm{ml})$, fruit length $(55.67 \mathrm{~mm})$, and peel weight $(0.96 \mathrm{gm})$ was observed in control $\mathrm{T}_{1}$ (Table 1).

This might be due to cell division in the initial stages and later due to cell expansion associated with movement of water and other metabolites into the cell causing increase in overall weight, volume, length, girth of the fruit. Similar results were reported by Kumbargire et al., (2016) on Banana, Ghasemi et al., (2013) in broad bean, Nesreen et al., (2011) in beans and Bhavya (2010) in grape.

The significant difference was noticed in total soluble solids due to soil application of silicon in guava. The maximum TSS $\left(12.05{ }^{\circ} \mathrm{B}\right)$ was found when plants were applied with (RDF + $3 \mathrm{~kg} \mathrm{DE} /$ plant) i.e. $\mathrm{T}_{9}$, while the lowest TSS $\left(9.82{ }^{0} \mathrm{~B}\right)$ was observed in the treatment $T_{1}$. The effects of diatomaceous earth on sugars to acid ratio varied significantly among the treatments.

The maximum sugars to acid ratio (21.03) was appeared in the treatment $\mathrm{T}_{9}(\mathrm{RDF}+3 \mathrm{~kg}$ DE/ plant) which was on par with the treatment $\mathrm{T}_{8}$ (14.96), $\mathrm{T}_{7}$ (14.75), $\mathrm{T}_{6}$ (14.53) and $\mathrm{T}_{5}$ (14.19), while the lowest value (5.86) was observed in the treatment $\mathrm{T}_{1}$ (Table 2) Silicon helped in synthesis of more sugars in the fruit and thus helped in increasing total soluble solids.
The results are in accordance with the findings of Bhavya (2010) in Bangalore Blue grapes, Rodrigues et al., (2010) in beans and Savvas (2009) in tomato. The titrable acidity varied significantly due to treatments. The minimum acidity $(0.18 \%)$ was found in $\mathrm{T}_{9}$ ( $\mathrm{RDF}+3 \mathrm{~kg} \mathrm{DE} /$ plant) while the maximum acidity $(0.33 \%)$ was noticed in the treatment $\mathrm{T}_{1}$ (Table 2).

The decrease in acidity might be due to increase in the total soluble solids and it was because of silicon, which might have either involved in fast conversion of metabolites into sugar and their derivatives. Similarly, Su et al., (2011) made observations in apple, Bhavya (2010) in Bangalore blue grapes, and Stamatakis et al., (2003) in tomato.

Maximum content of reducing sugar $(5.04 \%)$ was found in the fruits of $\mathrm{T}_{9}(\mathrm{RDF}+3 \mathrm{~kg} \mathrm{DE} /$ plant), while the minimum content of reducing sugar $(3.16 \%)$ was noticed in the treatment $\mathrm{T}_{1}$ which was on par with $\mathrm{T}_{2}(3.23 \%)$.

In case of non reducing sugars maximum content of non reducing sugar, $(0.66 \%)$ was found in the fruits of $\mathrm{T}_{9}(\mathrm{RDF}+3 \mathrm{~kg} \mathrm{DE} /$ plant) followed by $\mathrm{T}_{8}(5.59 \%)$, while the minimum content of non reducing sugar (4.98 $\%)$ was noticed in the treatment $\mathrm{T}_{1}$ which was on par with $\mathrm{T}_{4}(4.99 \%)$. The effects of diatomaceous earth on total sugars varied significantly among different treatments.

Maximum content of total sugar $(11.15 \%)$ was found in the fruits of $\mathrm{T}_{9}(\mathrm{RDF}+3 \mathrm{~kg} \mathrm{DE} /$ plant), while the minimum content of total sugar $(8.14 \%)$ was noticed in the treatment $\mathrm{T}_{1}$ (Table 2). This progressive increase could be related to increase in total soluble solids. Bhavya (2010) obtained the similar result in Bangalore Blue grapes, Su et al., (2011) in apple and Stamatakis et al., (2003) in tomato. 
Table.1 Effect of silica (DE) on physical parameter of guava fruits

\begin{tabular}{|c|c|c|c|c|c|}
\hline Treatments & Weight (g) & Volume (ml) & Girth (mm) & $\begin{array}{c}\text { Length } \\
(\mathrm{mm})\end{array}$ & $\begin{array}{c}\text { Peel } \\
\text { weight }(g)\end{array}$ \\
\hline $\mathbf{T}_{1}$ - Absolute control & 104.30 & 124.00 & 59.75 & 55.67 & 0.96 \\
\hline$T_{2}$ - Recommended dose of fertilizer (RDF) & 111.12 & 165.46 & 61.03 & 62.22 & 1.23 \\
\hline$T_{3}$ - Half of Recommended dose of fertilizer & 129.43 & 134.41 & 64.92 & 63.55 & 1.26 \\
\hline$T_{4}-$ Half of RDF + $1 \mathrm{~kg}$ DE/plant & 124.53 & 137.58 & 64.44 & 58.88 & 1.20 \\
\hline $\mathrm{T}_{5}$ - Half of RDF + $2 \mathrm{~kg}$ DE/plant & 127.50 & 149.10 & 58.17 & 60.85 & 1.18 \\
\hline$T_{6}-$ Half of RDF + $3 \mathrm{~kg}$ DE/plant & 131.91 & 136.33 & 62.84 & 60.73 & 1.27 \\
\hline $\mathrm{T}_{7}-\mathrm{RDF}+1 \mathrm{~kg} \mathrm{DE} /$ plant & 122.67 & 141.16 & 62.56 & 63.05 & 1.16 \\
\hline $\mathrm{T}_{8} \mathrm{RDF}+2 \mathrm{~kg} \mathrm{DE} / \mathrm{plant}$ & 137.75 & 141.83 & 62.23 & 61.78 & 1.11 \\
\hline $\mathrm{T}_{9}-\mathrm{RDF}+3 \mathrm{~kg} \mathrm{DE} /$ plant & 150.99 & 165.95 & 70.82 & 65.30 & 1.33 \\
\hline S.Em \pm & 2.13 & 1.12 & 1.37 & 0.77 & 0.04 \\
\hline C.D @ $5 \%$ ) & 6.40 & 3.36 & 4.13 & 2.32 & 0.12 \\
\hline
\end{tabular}


Table.2 Effect of silica (DE) on biochemical parameters of guava fruits

\begin{tabular}{|c|c|c|c|c|c|c|c|}
\hline Treatments & $\operatorname{TSS}\left({ }^{0} \mathbf{B}\right)$ & $\begin{array}{c}\text { Titrable } \\
\text { acidity } \\
(\%)\end{array}$ & $\begin{array}{c}\text { TSS:Acid } \\
\text { ratio }\end{array}$ & $\begin{array}{c}\text { Reducing } \\
\text { sugars (\%) }\end{array}$ & $\begin{array}{c}\text { Non } \\
\text { reducing } \\
\text { sugars }(\%) \\
\end{array}$ & $\begin{array}{c}\text { Total } \\
\text { sugars } \\
(\%) \\
\end{array}$ & $\begin{array}{c}\text { Ascorbic } \\
\text { acid } \\
\text { (mg/100gm) }\end{array}$ \\
\hline $\mathbf{T}_{1}$ - Absolute control & 9.82 & 0.33 & 27.03 & 3.16 & 4.98 & 8.14 & 134.50 \\
\hline$T_{2}$ - Recommended dose of fertilizer (RDF) & 11.60 & 0.32 & 36.49 & 3.23 & 5.12 & 8.35 & 165.57 \\
\hline $\mathbf{T}_{3}$ - Half of Recommended dose of fertilizer & 11.09 & 0.33 & 32.02 & 3.37 & 5.30 & 8.67 & 157.94 \\
\hline $\mathrm{T}_{4}-$ Half of RDF + $1 \mathrm{~kg} \mathrm{DE} /$ plant & 10.51 & 0.28 & 32.52 & 3.54 & 4.99 & 8.53 & 158.44 \\
\hline$T_{5}-$ Half of $\mathrm{RDF}+2 \mathrm{~kg} / \mathrm{plant}$ & 10.69 & 0.26 & 42.81 & 3.99 & 5.05 & 9.05 & 161.26 \\
\hline $\mathrm{T}_{6}-$ Half of RDF $+3 \mathrm{~kg} / \mathrm{plant}$ & 11.01 & 0.30 & 41.37 & 4.16 & 5.05 & 9.21 & 159.71 \\
\hline $\mathrm{T}_{7}-\mathrm{RDF}+1 \mathrm{~kg} \mathrm{DE} / \mathrm{plant}$ & 11.03 & 0.30 & 36.41 & 4.46 & 5.38 & 9.55 & 164.32 \\
\hline$T_{8-}$ RDF + 2 kg DE/plant & 11.43 & 0.22 & 52.61 & 4.86 & 5.69 & 10.63 & 169.08 \\
\hline T9. RDF + 3 kg DE/plant & 12.05 & 0.18 & 71.05 & 5.04 & 6.11 & 11.15 & 172.95 \\
\hline S.Em \pm & 0.14 & 0.01 & 0.97 & 0.05 & 0.12 & 0.10 & 0.37 \\
\hline CD@5\% & 0.42 & 0.05 & 2.91 & 0.10 & 0.36 & 0.32 & 1.94 \\
\hline
\end{tabular}




\section{Acknowledgement}

We thank Dr. N.B. Prakash, Professor, Department of Soil science and Agricultural chemistry, University of Agricultural Sciences, Bengaluru for providing Diatomaceous earth material for conducting this experiment.

\section{References}

Bhavya, H.K. 2010. Effect of foliar silicic acid and boron in Bengaluru Blue grapes, M. Sc. (Hort.) Thesis, Univ. Agric. Sci., Bengaluru, p. 95.

Epstein, E. 1999. Silicon-Annual review on plant physiology. Pl. Mol. Biol., 50: 641-644.

Ghasemi, A., Ejraei, A. and Rajaei, M. 2013. Effect of Silicon on vegetative and generative performance of Broad Bean (Vicia faba L.). J. Nov. Appl. Sci., 2(S): 881-884.

Gillman, J.H., Zlesak, D.C. and Smith, J.A. 2003. Applications of potassium silicate decrease black spot infection in Rosahybrida 'Meipelta'. Hort Sci., 38(6): 1144-1147.

Gong, H.J., Chen, K.M., Chen, G.C., Wang, S.M. and Zhang, C.L. 2003. Effect of silicon on growth of wheat. Emir. J. Food Agric., 19(2): 01-07.

Kumbargire, G.A., Swamy, G.S.K. and Anand Sadashiv Kalatippi 2016. Influence of Diatomaceous Earth as source of silicon on leaf nutrient status and yield attribute characters of banana $\mathrm{Cv}$. Grand Naine. The Bioscan, 11(1): 435-438.

Ma, J.F. and Takahashi, E. 2002. In: Soil, fertilizer, and plant silicon research in Japan. Elsevier, Amsterdam. pp. 1-20.

Ma, J.F., Goto, S. Tamai, K. and Ichii, M. 2001.
Role of root hairs and lateral roots in silicon uptake by rice. Plant Physiol., 127: 17731780.

Matichenkov, V.V. and Bocharnikova, E.A. 2010. Technology for natural water protection against pollution from cultivated areas, 2020. $15^{\text {th }}$ Annual Australian Agron. Conf., pp. $210-225$.

Matoh, T.S., Murata and Takahashi, E. 1991. Effect of silicate application on photosynthesis of rice plants. J. Soil Sci. Plant Nutr., 62: 248-251.

Melo, S.P., Korndorfer, C.M., Korndorfer, G.H., Lana, R.M. and Santan, D.G. 2003. Silicon accumulation and water deficient tolerance in grasses. Scientia Agricola., 60: 755-759.

Nesreen, H., Baker, A., Eladl, M. and Mohsen, M. A. 2011. Use of silicate and different cultivation practices in alleviating salt stress effect on bean plants. Australian J. Basic Appl. Sci., 5(9): 769-781.

Rodrigues, F.A., Duarte, H.S.S., Rezende, D.C., Filho, J.A., Korndrofer, G.H. and Zambolim, L. 2010. Foliar spray of potassium silicate on the control of angular leaf spot on beans. J. Pl. Nutr., 33(14): 2082-2093.

Savvas, D. 2009. Effect of silicon and salinity on fruit yield and quality of tomato grown hydroponically. Acta Hort., 609: 136-140.

Stamatakis, A., Papadantonakis, N., Simantiris, N., Kefalas, P. and Savvas, D. 2003. Effects of silicon and salinity on fruit yield and quality of tomato grown hydroponically. Acta Hort., 609: 141-147.

Su, X.W., Wei, S.C., Jiang, Y.M. and Huang, Y. 2011. Effects of Silicon on Quality of Apple Fruit and Mn Content in Plants on Acid Soils. Shandong Agric. Sci., 6(1): 2328.

\section{How to cite this article:}

Kishore Kumar Das, G.S.K. Swamy, Shivaningapp Kumbar, P.M. Gangadharappa and Jagadeesha, R.C. 2017. Effect of Silica on Physical and Biochemical characters of Guava. Int.J.Curr.Microbiol.App.Sci. 6(4): 1527-1532. doi: https://doi.org/10.20546/ijcmas.2017.604.187 